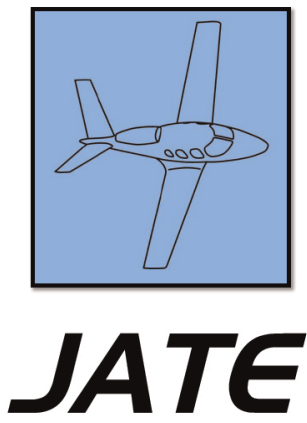

Journal of Aviation Technology and Engineering 4:1 (2014) 40-49

\title{
Airport Performance and Ownership Structure: Evidence from the United Kingdom, United States, and Latin America
}

\author{
Bijan Vasigh \\ Embry-Riddle Aeronautical University \\ G. Rod Erfani \\ Transylvania University \\ Brian W. Sherman \\ Embry-Riddle Aeronautical University
}

\begin{abstract}
This study investigates the operational and financial efficiency of airports in selected countries using a cross-regional analysis. A total factor productivity (TFP) approach is used to examine the operational and financial efficiencies of selected airports in the United States, the United Kingdom, and several Latin American countries. The empirical results indicate mixed implications and suggest that the privatized airports in the United Kingdom outperform the partially privatized, government-owned airports in Latin America; however, the evidence also suggests that the selected United States airports outperform the other two groups for each year of this investigation (20002010). The ambivalence of these results suggests that airport efficiency and productivity may be better evaluated in terms of market structure and competition rather than on the basis of ownership.
\end{abstract}

Keywords: $\quad$ airport, ownership, performance

\footnotetext{
About the Authors

Bijan Vasigh is a professor of economics and finance in the College of Business at Embry-Riddle Aeronautical University, Daytona Beach, Florida, and a managing director at Aviation Consulting Group, LLC. Vasigh received a Ph.D. in economics from the State University of New York, and he has written and published many articles and books concerning the aviation industry. Vasigh is author of North America's leading aviation textbook, An Introduction to Air Transport Economics: From Theory to Application, as well as Foundation of Airline Finance: Methodology and Practices, and Aircraft Finance: Strategies for Managing Capital Costs in a Turbulent Industry. He was a consultant with the International Civil Aviation Organization (ICAO) and provided assistance on the evolution of aeronautical charge structure for the Brazilian Institute of Civil Aviation (IAC). He also is a member of the international faculty at the International Air Transport Association (IATA) Learning Center. Correspondence concerning this article should be sent to vasighb@erau.edu.

G. Rod Erfani is a professor and director of economics at Transylvania University in Lexington, Kentucky. Erfani received his Ph.D. in economics from Florida State University, where he concentrated in international trade and finance. He also holds M.A. and B.S. degrees, both in economics. Prior to joining the economics faculty at Transylvania University in 1986, he was a professor at Spring Hill College, Alabama, and Central College, Iowa. Erfani has made professional presentations throughout the United States and in many foreign countries, including Austria, Brazil, Canada, England, France, Germany, Greece, Ireland, Italy, Mexico, and Romania. His current research interests are in the fields of international economics and economic development.

Brian W. Sherman is currently a revenue accountant for a regional U.S. airline. He graduated from Embry-Riddle Aeronautical University in 2013 with a Master of Business Administration and also holds a B.A. in economics and political science from the University of Connecticut.
} 


\section{Introduction}

Airport performance evaluation has become increasingly important to airport managers due to air transport liberalization, airline alliances, privatization, and global financial necessities. Performance evaluation can be split between operational efficiency and financial efficiency. Financial measurements allow airport managers to plan for financial resources and capital investment as efficiently as possible, an extremely important function as today's airport infrastructures are very expensive and take a long time to complete. Operational or technical efficiency measurements may be used as comparisons and guidelines in strategic planning.

Efficiency is a standard benchmark for economists and is widely used by many policy analysts in evaluating the outcome of privatization. Increasing passenger demand, escalating cargo expansion, increasing operating costs, and liability exposure have placed tremendous capital demands on government and state airport owners. As a result, governments recognize that private capital investment is needed to meet airport expansion, while commercialized management is needed to meet airports' operating efficiency and customer services. From the viewpoint of private investors and operators, airports can be profitable investments which operate as part of the vibrant transportation industry.

Today, many countries in Asia, Europe, and the Americas have privatized airports. Countries that have completed the sale or lease of airport facilities include: Argentina, Australia, Austria, Bahamas, Bolivia, Cambodia, Canada, Chile, China, Colombia, Denmark, Dominican Republic, Germany, Hungary, Italy, Japan, Malaysia, Mexico, New Zealand, Singapore, South Africa, and Switzerland. Presently, Japan is considering privatizing 94 of its 136 airports (CAPA, 2012). This plan, however, would exclude Japan's four main international airports: Narita, Kansai, Nagoya, and Haneda.

In Latin America, $90 \%$ of key airports are under partial or full private control (Buyck, 2007). Brazil, the country with the most airports in Latin America, successfully auctioned off three of its largest airports for the sum of \$14 billion early in 2012. However, transfer of a government monopoly to a private monopoly does not guarantee augmentation in efficiency or productivity unless it is accompanied by additional factors such as economic growth, increased airline presence, or enhanced competition. This premise may interpose with preconceptions that privately-operated airports are more efficient than government operators-or more simply_may reinforce the concept of major commercial airports as natural monopolies.

\section{Airport Privatization Techniques}

Governments around the world encourage private participation in management and operation of State-Owned Enterprises (SOEs) to enhance customer service, access capital, improve service delivery time, and reduce fiscal burden. Privatization is often encouraged as a means to reduce the government's role in economic activities; the airport industry is no exception. Building a new airport or adding a new runway requires large capital investments over a long period, usually at least ten years.

There are various ways in which the transfer of airports from public to private can occur, and each case is specific to the needs of a particular airport. Private investors may participate in airport ownership, management, and project investments. Privatization can encompass a range of different models that can be used to privatize airports, taking into consideration a broad definition of the privatization practice. Hence, it is imperative to choose a method in accordance with both macroeconomic and microeconomic objectives.

Furthermore, there are a seemingly unlimited number of ways in which to categorize how privatization takes place. For instance, the World Bank Group uses the following classification: (a) Greenfield, (b) concession, (c) management and lease contract, and (d) divestiture. Myers (2006) used the following categories: (a) Greenfield, (b) long-term lease, (c) government corporation buy-out, (d) partial share sale, and (e) privatization of services. In addition, Oum, Adler, and Yu (2006) used six categories: (a) government agency or department operating directly, (b) mixed privategovernment ownership with a private majority, (c) mixed government-private ownership with a government majority, (d) government ownership to management authority under long-term lease, (e) multilevel governments, and (f) $100 \%$ government corporation ownership.

For this paper, the methods of privatization are broken down as such: (a) no privatization, (b) contract management, (c) hybrid public-private partnerships, (d) concessions: buildoperate-transfer (BOT) and build-own-operate (BOO), (e) long-term leases, and (f) full and partial asset sales through Initial Public Offerings (IPOs). It is important to note that, unlike Oum et al. (2006), in which categorization directly affected the outcome of their analysis, the categories in this paper are used more to determine the structure of the different regions rather than their direct impact on the results. To this effect, the analysis that follows is divided into three general categories that span the majority of the privatization spectrum: selected airports from the United States (the US group) are comprised of methods (a), (b), and (c); the airports from Latin American (the LA group) are comprised of methods (a), (d), and (e); and lastly, the selected airports from the United Kingdom (the UK group) are comprised of methods from category (f). The authors will introduce these methods of privatization in order of their degree of private involvement, from least privatized to most privatized.

\section{No Privatization}

Before several of its largest airports were sold on leases, the overwhelming majority of Brazil's airports were under the direct ownership and control of Infraero, a national 
public company linked to the country's military and defense department. Only recently, with the growth of its economy coupled with the world showcases of the World Cup and Olympics, Brazil's airports became key candidates for private involvement as a means of developing new facilities and boosting passenger satisfaction. However, for the time period covered in this study (2000-2010), the selected airports from this country are considered as solely public organizations. Similarly, many smaller airports in Canada and the United States are operated under the budget of the cities, counties, and municipalities in which they reside. In many of these cases, the development and operational costs of such large facilities are far too great for any success as a private venture, and instead remain as services in the public domain.

\section{Airport Contract Management}

Contract management can be considered the least privatized form of airport ownership and involves certain parts of the airport being contracted out to private companies (such as restaurants, parking facilities, baggage handling, cargo, security, fueling, and basic maintenance). This type of agreement usually does not carry a large investment commitment and by far is the most common form of privatization. Under this method, the government still holds management and operational control of the airport. In most cases, airports will use this type of privatization in order to reduce costs and increase revenues. Similarly, in some instances, governments may grant contracts for larger operations, such as an entire terminal or even overall management of the airport to the private sector.

\section{Hybrid Public-Private Partnership}

In some countries, especially in the United States, there are certain public-private agreements that cannot appropriately be placed into the other categories mentioned in this paper. In these contracts, concessions, and longer term leases, the government entity responsible for airport operations will hire a private firm to complete a project to develop or modernize facilities. However, in the US, where individual airlines often have significant control over terminals and general airport operations, projects such as terminal renovation take on a hybrid form of a publicprivate partnership.

Prime examples of the Hybrid Public-Private Partnership are the terminals at JFK International Airport in New York. Terminal 1 was renovated and reopened in 1998 by a partnership (Terminal One Group) of Air France, Japan Airlines, Korean Air, and Lufthansa at a cost of $\$ 435$ million. JFK's Terminal 4, which was overhauled in 2001 by JFK IAT LLC, is under a two-phase expansion and renovation project, Phase 1 of which was completed on
May 24, 2013, and Phase 2, which began in June 2013, and it is scheduled for operation in 2015 (JFK IAT, 2013). Airlines investing in airport infrastructure can also be seen in other places in the United States, especially in fuel distribution. The LAX Fuel Corporation is a consortium of airlines that contracts fuel distribution to a third party (Aircraft Service International Group [ASIG]) outside the direct control of the airport.

A slightly different partnership encompasses Orlando Sanford International Airport and Bob Hope Airport in Burbank, California. Both airports are owned by local governments that have contracted management of the airport to TBI Airport Management, Inc. At Orlando Sanford, TBI manages both international and domestic terminals and is responsible to develop additional air service and provide ground handling and cargo services (Orlando Sanford Airport, 2012). However, the Sanford Airport Authority is still responsible for all air-side activities, as well as the properties surrounding the airfield. TBI also operates several other airports, including three airports in Bolivia. Abertis Infraestructuras, a Spanish corporation, owns a $90 \%$ stake in TBI via a holding company and manages toll roads and communication infrastructure as well as airports. The remaining $10 \%$ stake is owned by Aena Internacional, a Spanish governmentowned airport operator (Abertis, 2012).

\section{Build-Operate-Transfer and Build-Own-Operate}

Concession agreements are very common practices of governments securing private involvement in development projects under a competitive bidding process. These concessions are a specific type of contract that usually lasts from 15-30 years, depending on the nature of the project. As such, they are considered to have a higher degree of privatization than generic contract management, but are considered less so than longer term lease arrangements.

Under the build-operate-transfer (BOT) method, a private investor will build and operate a governmentowned airport and gain revenue from the operation. Then, after a certain period, the operator transfers the ownership of the facility back to the government. This is used in order to create enough revenue to build large infrastructures. For example, the Chilean government is retendering the concession at La Serna airport in northern Chile. The current contract ends in 2013 and the government is currently looking for new bidders on an $\$ 8$ million investment to remodel the terminal building (Uphoff, 2012). Terminal 3 in Lester B. Pearson Airport in Toronto, Canada was built as a Build-Own-OperateTransfer (BOOT) agreement between the governmentowned Transport Canada and Lockheed Air Terminal of Canada, Inc. (Juan, 1996). The terminal was built in 1991 for $\$ 570$ million under a 60 -year land lease, but the contract 
was broken in 1997 and the terminal was purchased by the government (Bryden, 1997).

Concession agreements are very safe ways of moving the risks of project development from the public sector to the private sector. This approach is mainly used when airport capacity needs to be expanded. It has the characteristics of a long-term franchise for infrastructure facilities under which projects are built, operated, and eventually transferred to the government in contractual agreements with private sectors parties. Private consortia are often able to design and build large facilities in less time than is possible through traditional government procurement methods. In 2005, a consortium headed by Hochtief Airport won a 20 -year concession at Tirana Airport in Albania. The consortium was comprised of Hochtief (47\%), the Albanian American Enterprise Fund (21.3\%), and a German investment corporation, DEG (31.7\%) (Turner, 2004). In addition, the up-front and operating costs can be lowered to generate long-term profitability.

Developments of entirely new airports under BOT schemes are uncommon in comparison to smaller concession projects. Nonetheless, the new Athens International Airport was completed in 2001 under a BOT agreement between the Greek government and a consortium headed by Hochtief AirPort for the duration of 25 years. The new Berlin-Brandenburg Airport was planned to be built under a BOT agreement to be finished in 2012; however, after several delays, the airport is now scheduled to begin operations in October of 2016. These delays have forced airlines to reroute previously scheduled flights and initial private contracts have been terminated (Gubisch, 2012). Under the Build-Own-Operate method, the private entity remains the owner of the project for the lifetime of the project.

\section{Long-Term Lease}

The long-term lease option turns over a large portion of the airport to private investors. Typically, the lease payment is paid to the government on a percentage of the gross revenue, and therefore creates an incentive to minimize costs. The long-term lease agreement is used when the facility under contract requires substantial new development. The goal of the government is to transfer investment and risk away from the government to a private lessee. Fees and airport usage charges are directly paid to the lessee, whereas the government receives a percentage of the gross revenues. Long-term leases are similar to concession agreements, but the substantial differences in size and scope allocate for a higher degree of private involvement. Australia has successfully used this method in the privatization of their major airports by first consolidating its airports into a government corporation and then privatizing in phases through lease agreements. In 1997, the Australian government raised more than $\$ 2.6$ billion through the sale of
Melbourne, Brisbane, and Perth airports (TTF Australia, 2007). It followed this trend in 2002 with the sale of Sydney Airport to the Southern Cross consortium for US \$3.2 billion (Ionides, 2002).

\section{Full and Partial Asset Sale}

The next most widely used method and the highest level of private involvement is one in which the private company owns the entire equity of the airport, including its terminals and other facilities, operates the airport, and invests in capital expenditures. Governments offer the airport at an auction to which the highest bidder will receive either a portion or the entire airport ownership. In this type, the earnings from the sale usually go to reducing outstanding government debts or for other investment projects. Governments usually sell when they believe the airport is more efficiently operated by the private sector, or the government is experiencing economic loss from operating the airport. The government of New Zealand had this in mind when it created Auckland International Airport Limited and gradually divested its shares to the private sector and local governments since 1998 (ICAO, 2011). Since that time, many airports in Argentina, Australia, Austria, Bahamas, Bolivia, Cambodia, Canada, Chile, China, Colombia, Denmark, Dominican Republic, Germany, Hungary, Italy, Japan, Malaysia, Mexico, New Zealand, Singapore, South Africa, Switzerland, and Venezuela have been fully or partially privatized in a similar manner.

Initial Public Offerings (IPOs) are based on the first-time offering of shares to public investors. The most widely known IPO transaction took place in 1987 when Prime Minister Thatcher proposed to sell off the British Airports Authority. Some governments prefer to retain a minority or majority vote in the airport. In this case, airports will sell partial interests. As of 2006, the Beijing International Airport Co. Ltd. listed 1.5 billion shares as "H shares" and 800 million shares as "A shares", while 2.5 billion shares $(51 \%)$ were kept under ownership of the governmentowned company (BCIA, 2012). Similarly, the government of Thailand listed its airports on the national stock exchange through a partial privatization (30\%) to raise cash to help finance Bangkok's new airport (Fullbrook, 2002).

\section{Literature Review}

While over 100 airports around the world are either privatized or are in the process of being transferred to private enterprises, the privatization of airports has received mixed reviews. Proponents argue that the benefits of airport privatization include efficiency gains through the transfer of ownership and management of public airports to private owners and managers (Poole, 1997). Privatization contributes to the improvement of airport amenities and enhances financial efficiencies in the form of increased 
revenues and profits. In contrast, those opposed to privatizing airports state that the airport industry is a natural monopoly, and therefore should be regulated by the government. In addition, there are concerns that privatization of an airport will take away the profit from the airport without reinvesting it back into airport infrastructure. Those against privatization argue that government ownership may have several potential advantages over private ownership, the most important being the pursuit of socially desirable objectives. These may include higher employment level, production of socially desirable products, and public goods.

In a 2003 study, Vasigh and Haririan could not support superiority of private airports over public airports. However, other studies such as Oum, Yu, and Fu (2003) and Oum, Zhang, and Zhang (2004) indicate that the airports owned by mixed enterprises with a private sector majority ownership are more efficient than airports owned by government branches or a $100 \%$ public corporation. Despite dozens of studies evaluating the productivity of airports and many more focusing on ownership and privatization, only a few have addressed the relative productivity of private versus public airports in terms of both operational and financial efficiencies.

In a study by Vasigh and Hamzaee (1998), it was concluded that privatization can only be accepted or rejected on the basis of theory, politics, or ideology. Another study by Vasigh and Haririan (2003) investigated the financial and operational efficiency of private versus public airports by using fifteen airports (both public and private) chosen by their similarity in hub size. These results showed that there is a statistically significant difference between the two types of ownership. Public enterprises were shown to have better financial efficiency in this aspect. For privatized airports, the cost per runway was lower than that for public airports; alternatively, the passengers per runway was higher for public airports than private airports.

A study by Vasigh and Gorjidooz (2006) tested productivity in public and private airports using 22 US and EU airports over five years. They concluded that the productivity and efficiency depend on market power, regulatory control, and the level of competition in the environment in which they operate.

In the book, The Official History of Privatisation (2012), author David Parker discusses price cap regulation in the form of retail prices index, which is at a basic level considered at RPI minus one based on yield and consistency with the single till approach. The cap limits the maximum allowable revenue yield per passenger that can be levied by way of airport charges.

There are a number of techniques that have been applied to measure airport efficiencies, including ratio analysis, regression analysis, data envelopment analysis (DEA), and total factor productivity. Gillen and Lall (1997) adopted a data envelopment analysis and a Tobit Model to measure and rank the productivity of 21 top US airports, using data from 1989-1993. Sarkis (2000) used DEA to measure 44 US airports from 1990-1994, and Martin and Roman (2001) applied the DEA method to analyze the technical efficiency and performance of several Spanish airports. A major attractiveness of DEA is its ability to handle multiple inputs and outputs to derive relative efficiencies.

Hooper and Hensher (1997) used a nonparametric index number method to test the productivity of six Australian airports over four fiscal years, 1989-1991. This study also included an investigation to apply the concepts of total factor productivity specifically to the airport sector. Following the Federal Airports Corporation Act in 1986, Abbott and Wu (2002) applied both TFP and DEA to Australian airports in the 1990s to study productivity growth. Oum et al. (2003) analyzed 50 major airports using TFP regression models that suggested that ownership structure does not have a strong effect on productivity and performance. In another study, Yoshida (2004) expanded the investigation on the application of TFP in an analysis of 30 airports in Japan for the year 2000, using terminal size and total runway length as input variables, and cargo, passenger handling volumes, and aircraft movements as output variables.

The traditional TFP model was developed by Caves et al. (1982) and applied by Hooper and Hensher (1997) to the airport sector. This translog multilateral productivity index is weighted using revenue and cost shares of respective output and input variables. However, as pointed out in a study by Oum et al. (2003), a major obstacle in employing the traditional TFP model is a lack of transparent financial data of airport operators that would allow output and input variables to be matched with their appropriate revenue or cost shares. As a result, both Oum et al. (2003) and Yoshida (2004) applied what has been termed as the "Endogenous-Weighted" system to the TFP ratio index as a means of benchmarking the technical efficiency of airports in their research. This "EW-TFP" method does not need revenue or price data, but still requires the same sensitivity that the DEA method provides.

\section{Method}

The authors divided selected airports into three very different and distinctive groups: the United States group, the United Kingdom group, and the Latin American group. The UK group is composed of six airports, while the US and Latin American groups are composed of nine and eleven airports, respectively (see Table 1). In the United States, all major commercial airports have been traditionally independent of national control, being owned and operated by municipalities or regional authorities and influenced by private interests, such as airlines and general aviation. As a result, US airports are considered to be fully public airports controlled by various local government 
Table 1

Selected airports by group.

\begin{tabular}{|c|c|c|c|c|c|c|}
\hline Airport Name & IATA Code & $\begin{array}{l}\text { Passengers } \\
\text { (in 1000s) }\end{array}$ & $\begin{array}{l}\text { Aircraft Movements } \\
\quad \text { (in 1000s) }\end{array}$ & $\begin{array}{l}\text { Revenues } \\
\quad(\$ M)\end{array}$ & $\begin{array}{l}\text { Expenses } \\
(\$ M)\end{array}$ & $\begin{array}{l}\text { Total Runway } \\
\text { Area (sq. ft.) }\end{array}$ \\
\hline \multicolumn{7}{|c|}{ United Kingdom Group } \\
\hline HEATHROW & LHR & $69,391.40$ & 476.2 & $2,944.73$ & $2,161.96$ & $3,875,184$ \\
\hline GATWICK & LGW & $33,674.26$ & 251.07 & 707.73 & 565.23 & $2,855,512$ \\
\hline STANSTED & STN & $18,042.40$ & 136.9 & 348.29 & 289.75 & $1,500,000$ \\
\hline EDINBURGH & EDI & $9,384.70$ & 105.8 & 140.78 & 105.72 & $1,863,642$ \\
\hline GLASGOW INTL & GLA & $6,864.00$ & 70.5 & 203.9 & 86.53 & 546,922 \\
\hline SOUTHAMPTON & SOU & $1,762.50$ & 45.7 & 74.47 & 70.28 & 684,013 \\
\hline \multicolumn{7}{|c|}{ Latin American Group } \\
\hline GUARULHOS INTL & GRU & $30,003.43$ & 270.6 & 489.97 & 231.66 & $3,253,484$ \\
\hline RIO DE JANEIRO INTL & GIG & $14,952.83$ & 139.44 & 323.95 & 205.19 & $3,548,886$ \\
\hline CANCUN INTL & CUN & $13,112.00$ & 121 & 263.25 & 139.04 & $2,262,151$ \\
\hline LUIS R MAGALHAES & SSA & $8,394.90$ & 125.98 & 78.07 & 45.64 & $2,196,912$ \\
\hline SALGADO FILHO & POA & $7,834.31$ & 99.58 & 90.35 & 56.98 & $1,047,340$ \\
\hline MIGUEL HIDALGO & GDL & $7,225.00$ & 129.98 & 127.88 & 65.83 & $3,145,847$ \\
\hline GUARARAPES INTL & REC & $6,383.37$ & 83.64 & 79.05 & 55.09 & $3,253,484$ \\
\hline GRAL. MARIANO ESCOBEDO & MTY & $5,642.00$ & 86 & 89.54 & 78.05 & $2,035,846$ \\
\hline MARISCAL SUCRE & UIO & $5,547.00$ & 82 & 148.97 & 67.79 & $1,545,636$ \\
\hline GEN. RODRIGUEZ & TIJ & $3,534.00$ & 42.47 & 54.26 & 40.68 & $1,398,384$ \\
\hline JUAN SANTAMARIA INTL & SJO & $3,420.00$ & 64 & 22.93 & 11.31 & $1,492,031$ \\
\hline \multicolumn{7}{|c|}{ United States Group } \\
\hline HARTSFIELD & ATL & $92,389.02$ & 924 & 411.21 & 203.38 & $7,333,500$ \\
\hline O'HARE INTL & ORD & $66,659.71$ & 878.8 & 679.4 & 609.5 & $9,153,650$ \\
\hline LOS ANGELES INTL & LAX & $61,862.05$ & 702.9 & 855.5 & 747.73 & $6,914,350$ \\
\hline DALLAS-FT. WORTH & DFW & $57,744.55$ & 646.8 & 514.6 & 611.47 & $15,324,610$ \\
\hline DENVER & DEN & $52,849.13$ & 628.8 & 602.77 & 571.93 & $16,400,000$ \\
\hline JOHN F. KENNEDY INTL & JFK & $47,683.53$ & 411.23 & $1,068.76$ & 903.23 & $7,068,450$ \\
\hline GEORGE BUSH INTERCONTL & IAH & $40,128.95$ & 517.26 & 410.4 & 447.36 & $7,560,300$ \\
\hline ORLANDO INTL & MCO & $35,426.01$ & 309.88 & 358.38 & 320.53 & $7,651,800$ \\
\hline LA GUARDIA & LGA & $24,122.48$ & 366.6 & 334.14 & 288.48 & $2,100,000$ \\
\hline
\end{tabular}

Sources: 2010 Financial Reports of Airports, Flightglobal, and ICAO Data.

agencies. In contrast, the UK group represents fully privatized airports, while the Latin American group is composed of a mix of government-owned and privatelyoperated airports selected by countries throughout Latin America, including Mexico. The major source of data for the airports in these groups was acquired by the authors utilizing the ICAO Database and Flightglobal. For US airports, financial information was provided via FAA Report 127. UK airport information was taken from the yearly Airports Statistics, which includes the UK Airports Industry Statistical Series published by the University of Bath.

The authors also wish to make mention of the potential effects that airport size has on efficiency calculations used in this study. For instance, by looking at annual passenger averages, the selected Latin American airports have an average of 7,671,636 passengers compared to $24,479,500$ for the UK and 54,369,222 for the selected US airports. While selecting different airports will surely yield different results, it does pose the question of the true impact of comparing airports with such diverse characteristics and the role of economies of scale in such an analysis. Furthermore, when interpreting the data and results, it is important to remember that nonprofit and for-profit organizations are being compared with the same standards, although they have different functional and managerial objectives.

\section{Productivity Analysis}

In order to evaluate performance of airport operations, the role of productivity and its measurement become important for both public and private entities. As mentioned earlier, there are a number of techniques that have been adopted and applied to measure airport productivity, including single ratio analysis, multivariate ratio indexing, total factor productivity, Data Envelopment Analysis, and Stochastic Frontier Analysis (SFA). Productivity is defined as the ratio of the outputs to inputs, and for this study, is divided into two separate components: technical (operational) efficiency and financial efficiency. This section describes the nonparametric methods used in this paper to determine the results of our observation.

\section{Technical (operational) efficiency}

In this paper, the authors utilize the multilateral TFP index introduced by Caves et al. (1982), expanded by Hooper and Hensher (1997), and utilized by Oum et al. 
(2003) and Yoshida (2004) in order to estimate the technical efficiency of the selected airports. This model is based on the Cobb-Douglas production function and the assumption that the production process exhibits constant returns to scale and is used to represent the relationship of an output to inputs. If technological knowledge in all airports is more or less the same, then one can assume that productivity in all such airports will be the same. This means that the same quantities of output would be produced by given quantities of inputs such as runway, gates, and labor. Of course, this hypothetical relationship has been challenged by many empirical works, such as Trefler's (1993) macroeconomic applications. One of the best explanations of the TFP method is arguably that which Harrigan (1997) has offered in his theoretical and empirical cross-country comparisons of industry TFP.

However, whereas the traditional TFP model uses revenue and cost shares as weights for each variable, the following technical efficiency evaluation utilizes the "Endogenous-Weighted" system developed by Oum et al. (2003) and Yoshida (2004). Under this system, greater emphasis is placed on those variables which show the least variation (or standard deviation) amongst themselves in each year of the data set. This EW-TFP is used to create a productivity index based upon the ratio of the products of selected outputs with the products of selected inputs. The multilateral TFP index formula used by Hooper and Hensher (1997) was modified by Yoshida (2004). This modified formula replaces revenue and cost-based weights with an "endogenous" weighting system that places emphasis on those variables which show lower variation (or standard deviation) each year while still maintaining the constant returns to scale assumption. Total factor productivity ratios, or technical efficiency ratings, can be measured using the translog multilateral productivity index developed by Caves et al. (1982) and expanded by Hooper and Hensher (1997).

$$
\begin{aligned}
\ln \frac{T F P_{k}}{T F P_{b}}= & \frac{1}{2} \sum\left(R_{k j}+\bar{R}_{j}\right)\left(\ln Q_{k j}-\overline{\ln Q_{J}}\right) \\
& -\frac{1}{2} \sum\left(R_{b j}+\bar{R}_{j}\right)\left(\ln Q_{b j}-\overline{\ln Q_{J}}\right) \\
& -\frac{1}{2} \sum\left(S_{k i}+\bar{S}_{i}\right)\left(\ln I_{k i}-\overline{\ln I_{I}}\right) \\
& +\frac{1}{2} \sum\left(S_{b i}+\bar{S}_{i}\right)\left(\ln I_{b i}-\overline{\ln I_{I}}\right)
\end{aligned}
$$

where:

$\mathrm{TFP}_{\mathrm{k}}$ is the technical efficiency rating of the k-th airport $\mathrm{TFP}_{\mathrm{b}}$ is the technical efficiency rating of the base airport $\mathrm{k}$ is the number of individual airport observation, $\mathrm{k}=1$, ..., K

$\mathrm{b}$ is the base observation (selected airport)

$\mathrm{j}$ is the number of outputs, $\mathrm{j}=1, \ldots, \mathrm{J}$

$\mathrm{i}$ is the number of inputs, $\mathrm{i}=1, \ldots, \mathrm{I}$
$\mathrm{R}_{\mathrm{j}}$ is the weight for each output

$\bar{R}_{j}$ is the geometric mean of output weights over all observations

$\mathrm{S}_{\mathrm{i}}$ is the weight for each input

$\bar{S}_{i}$ is the geometric mean of input weights over all observations

$\ln Q_{j}$ is the unit measure of output

$\overline{\ln Q_{J}}$ is the geometric mean of output weights over all observations

$\ln \mathrm{I}_{\mathrm{i}}$ is the unit measure of input

$\overline{\ln I_{I}}$ is the geometric mean of input weights over all observations

In this study the following inputs and outputs are used in the analysis:

Outputs $(\mathrm{Q})$ :

- Number of passengers

- Number of aircraft movements

- Freight (metric tons)

- Average aircraft size (in terms of passengers)

Inputs (I):

- Terminal space (square feet)

- Number of gates (Remote gates and hardstands included)

- Runway Area (square feet)

\section{Financial efficiency}

If there was complete dissemination of financial information for the selected airports, these figures could be substituted into the TFP analysis to be used as price weights for appropriate variables. However, as only aggregate information is available for all the selected airports, the financial efficiency must be examined separately as combining the financial aggregates with the technical efficiency model would require very loose assumptions and approximations. As such, for this section of the analysis, a total revenue/total expense ratio is calculated and indexed so each airport and airport group can be compared side-by-side on a financial basis, and then cross-compared with the technical efficiency index.

It should be noted that a substantial portion of US airports' total revenues are a result of government grants, which are accounted for under nonoperating revenue and thus boost an airport's total revenue, perhaps artificially, and may create an overestimation of the airport's actual revenue. However, two factors overcome this limitation. First, because the FAA limits the passenger facility charge that any US airport can levy, one can defend that airport revenues are artificially lowered by this price ceiling, and any received government grants merely replace this lost revenue. Secondly, one core argument in favor of privatization is the ease of acquiring capital for the airport's projects, and thus the inclusion of nonoperating income in the total revenue aggregate creates an additional basis for comparison. 


\section{Group Technical Efficiency Index}

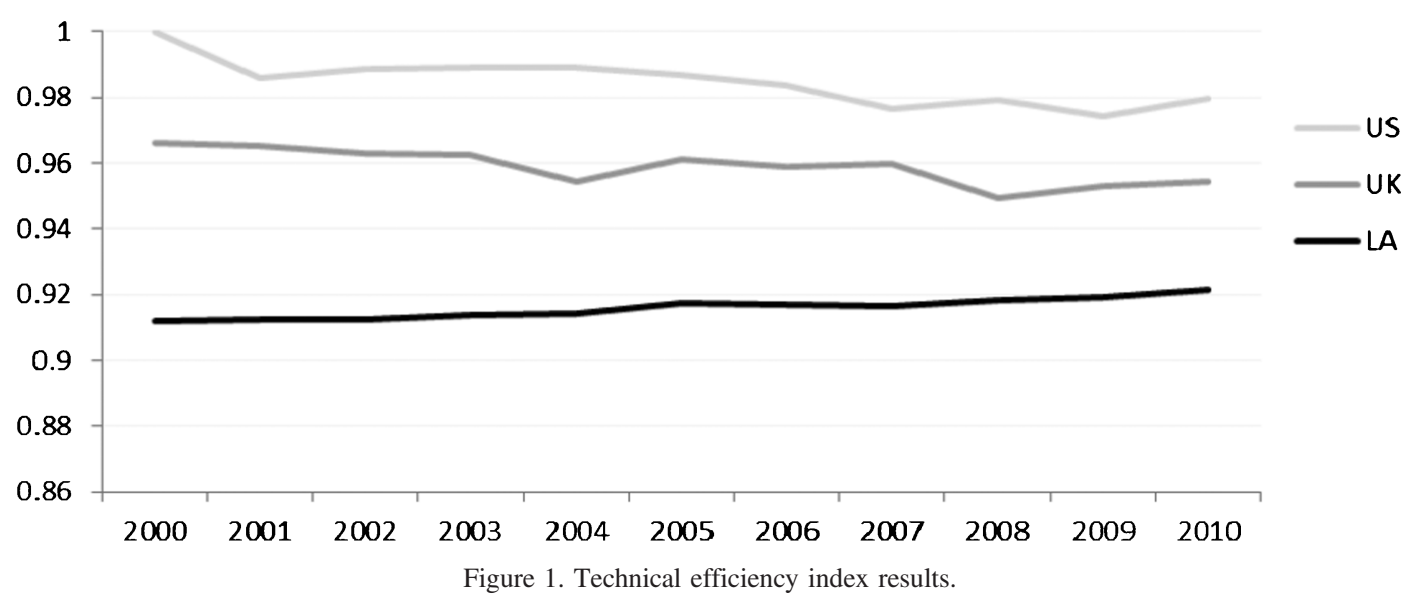

\section{Empirical Analysis}

\section{Technical efficiency index}

The technical efficiency index results obtained from the EW-TFP model for the selected airport groups are displayed in Figure 1.

The drop in productivity in the US group in 2001 may be due to the events of September 11th (9/11) and its resulting aftermath. Post 9/11, many airlines and airports experienced a long period of decreasing demand which was beyond the control of airport managers. Based on our analysis, the US airports are the most technically efficient group in our sample analysis. Both UK and US groups outperform the LA group; however, the evidence suggests that the airports within the LA group have steadily increased their efficiency while the others have declined over the last decade. Economic and air transport growth, experimentation in privatization practices, and an increase in professional know-how may all help explain this trend.

\section{Financial efficiency index}

The financial efficiency index results are shown in Figure 2. Although the group rankings are generally the same, there is much greater variability in the financial index than in the operational index. This can be explained from large, one-time nonrevenue gains and expenditures for facility development and expansion, even though annual upkeep and operations remain more stable.

Comparing the two indices, the results show a weak but positive connection between technical efficiency (productivity) and financial efficiency (profitability) with a correlation coefficient of 0.60 . Figure 3 further illustrates the distinct differences between the three groups included in the study.

\section{Conclusion}

This study investigates the operational and financial efficiencies of selected privatized airports in the United Kingdom, selected public airports in the United States, and

\section{Group Financial Efficiency Index}

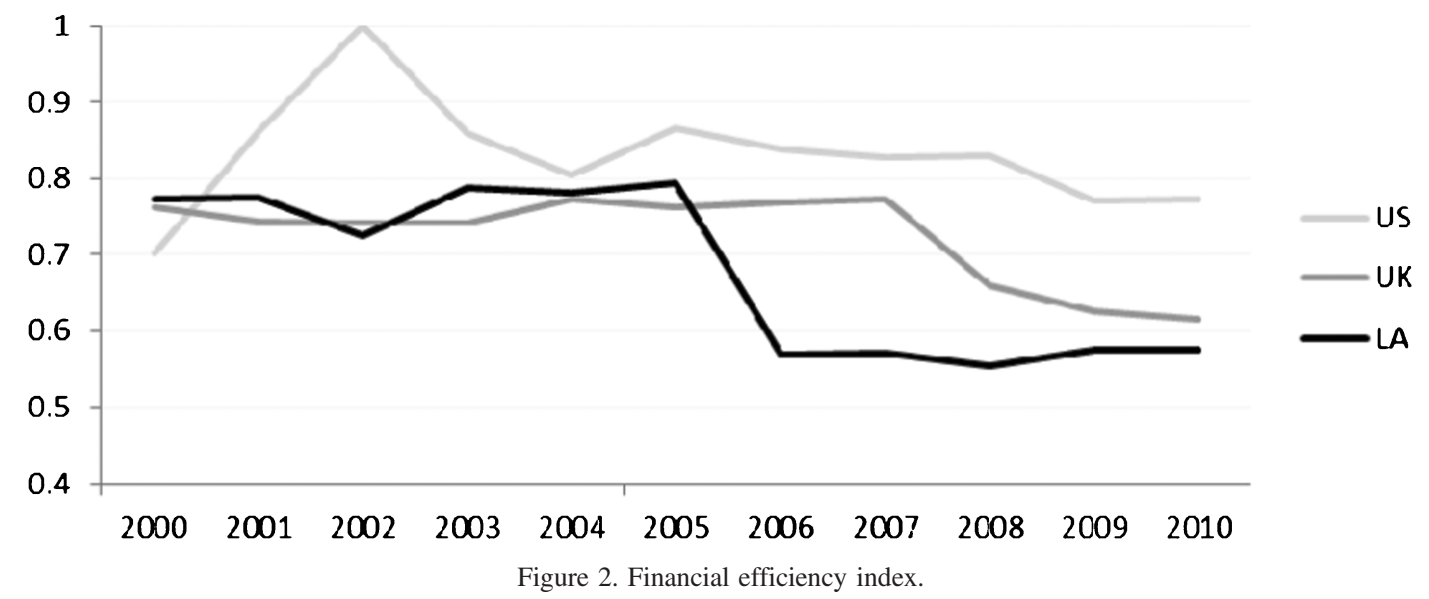




\section{Group Productivity vs Profitability}

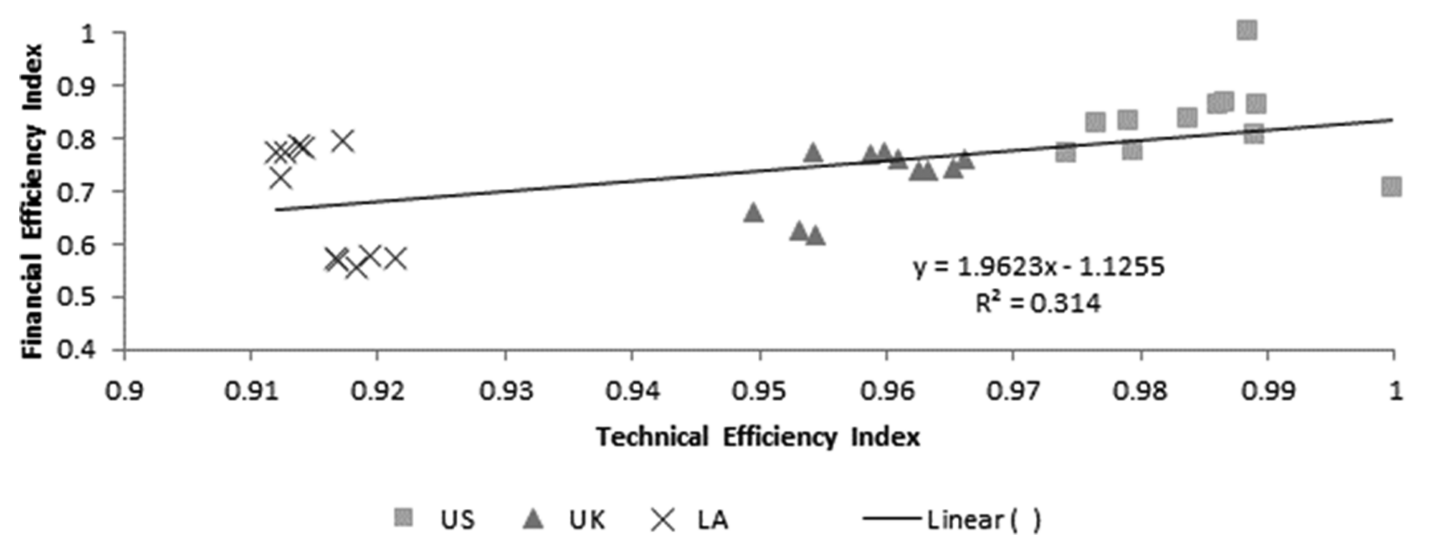

Figure 3. Group productivity and profitability comparison.

selected airports in Latin America. The main objective of this paper is to analyze and measure the performance of several different groups of airports, categorized based upon degree of private involvement in airport operations. One should bear in mind that productivity is influenced by government regulation, airport-airline usage agreements, work methods, capital, quality, technology, weather conditions, and position of runways.

Based on the endogenous-weighted TFP model used to measure technical and operational efficiency, US airports outperformed those airports within the UK and LA groups. There was a similar outcome in terms of the financial efficiency index, except that the LA group outperformed the UK group in five of the years during the study period. However, there is no conclusive evidence to suggest a trend between private involvement and airport performance.

Many studies suggest that the debate on public versus private airports cannot be empirically decided, and that economic and political factors need to be considered in each case. Privatization is not a panacea to resolve the problems of poorly managed public entities. Airports are monopolistic, or at best oligopolistic, in character and as such, transfer of ownership from a public monopoly to a private monopoly may not guarantee higher productivity and efficiency. Airport privatization, in several cases, had a negative effect on the industry as the newly created monopolies have taken advantage of their dominant position.

The productivity and efficiency of airports depend on the market power, regulatory control, and competitive conditions in which the airports operate. Promoting a competitive environment or enacting a proper regulatory regime yields substantial benefits. As mentioned before, the sheer size of an airport may have a strong effect on the nature of efficiency due to synergies and economies of scale. Clearly, further empirical studies are required to assess the relationship between ownership structure and productivity at commercial airports.

\section{References}

Abbott, M., \& Wu, S. (2002). Total factor productivity and efficiency of Australian airports, Australian Economic Review, 35(1), 244-260.

Beijing Capital International Airport (BCIA). (2012). Investor relations: Information on $\mathrm{H}$ shares and corporate bonds. Retrieved from http://en. bcia.com.cn/investor/index.shtml

Buyck, C. (2007, June). Public monopolies, private profits. Air Transport World, June 2007: 5. Academic Search Premier. EBSCO.

Bryden, J. (1997, April 2). Settlement near over cancelled airport contract. Toronto Star, p. B3.

CAPA Centre for Aviation (2012, January 23). Japan considers privatization of 94 airports.

Caves, D., Christensen, L., \& Diewert, E. (1982). Multilateral comparisons of output, input, and productivity using superlative index numbers. The Economic Journal, 92(365), 73-86.

Fullbrook, D. (2002, July 3). Airports Authority of Thailand IPO set for October. Flightglobal.

Gillen, D., \& Lall, A. (1997). Developing measures of airport productivity and performance: An application of data envelopment analysis. Transportation Research, Part E, 33(4), 261-273.

Gubisch, L. (2012, May 17). Berlin Brandenburg Airport delayed until 17 March, Flightglobal.

Harrigan, J. (1997). Cross-country comparisons of industry total factor productivity: Theory and evidence. New York: Federal Reserve Bank of New York.

Hooper, P. G. \& Hensher, D. A. (1997). Measuring total factor productivity of airports: An index number approach. Transportation Research, Part E, 33(4), 249-259.

ICAO. (2011, June 28). Case study: New Zealand. Retrieved from http:// www.icao.int/sustainability/CaseStudies/New\%20Zealand.pdf

Ionides, N. (2002, June 25). Australia sells Sydney Airport for A $\$ 5.58$ billion. Flightglobal.

JFK IAT. (2007). Airport history. Retrieved from http://www.jfkiat.com/ history.html

Juan, E. (1996). Privatizing airports: Options and case studies. Public Policy for the Private Sector, The World Bank, Note No. 82.

Martin, J. C., \& Roman, C. (2001). An application of DEA to measure the efficiency of Spanish airports prior to privatization, Journal of Air Transport Management, 7(3) 149-157.

Myers, A. (2006). Airport privatization: The effects of take off. Centre for Civil Society, Working paper No. 152.

Oum, T. H., Yu, C., \& Fu, X. (2003). A comparative analysis of productivity performance of the world's major airports. Journal of Air Transport Management, 9(5), 285-297. 
Oum, T. H., Zhang, A., \& Zhang, Y. (2004). Alternative forms of economic regulation and their efficiency implications for airports. Journal of Transport Economics and Policy, 38(2), 217-246.

Oum, T. H., Adler, N., \& Yu, C. (2006). Privatization, corporatization, ownership forms and their effects on the performance of the world's major airports. Journal of Air Transport Management, 12, 109-121.

Parker, D. (2012). The official history of privatisation (Vol. II). Florence, KY. Routledge.

Poole Jr., R. (1997, September). Privatization: A new transportation paradigm. Annals of the American Academy of Political and Social Science, 553, 94-105.

Sarkis, J. (2000). An analysis of the operational efficiency of major airports in the United States. Journal of Operations Management 18(3), 335 .

Trefler, D. (1993). Trade liberalization and the theory of endogenous protection: An econometric study of U. S. import policy. The Journal of Political Economy, 101(1), 138.
Tourism and Transport Forum (TTF Australia), (2007). Assessing the impact of airport privatization: Final report. URS Australia Pty. Ltd.

Turner, A. (2004, October 15). Hochtief Airport to operate Tirana Airport. Flightglobal.

Uphoff, R. (2012, July 5). Chile retenders La Serena airport concession. Flightglobal.

Vasigh, B., \& Gorjidooz J. (2006). Productivity analysis of public and private airports: A casual investigation. Journal of Air Transport Management, 11(3), 144-162.

Vasigh, B., \& Haririan, M. (2003). An empirical investigation of financial and operational efficiency of private versus public airports. Journal of Air Transportation, 8 (1), 91-110.

Vasigh, B., \& Hamzaee, R. (1998). A comparative analysis of economic performance of U. S. commercial airports. Journal of Air Transportation Management, 4(4), 209-216.

Yoshida, Y. (2004). Endogenous-weight TFP measurement: Methodology and its application to Japanese-airport benchmarking. Transportation Research, Part E. 44, 151-182. 